\title{
Correction to: Special Section of Familial Organizations and International Business: Individual, Organizational and Institutional Variety in and beyond Asia
}

\author{
Kimberly A. Eddleston ${ }^{1}$ • Peter Jaskiewicz ${ }^{2}$ - Mike Wright ${ }^{3,4}$ \\ Published online: 23 May 2020 \\ (C) Springer Science+Business Media, LLC, part of Springer Nature 2020
}

\section{Correction to: Asia Pacific Journal of Management (2020) 37: 127-153} https://doi.org/10.1007/s10490-018-9593-9

\section{Asia Pacific Journal of Management (2020) 37: 205-225} https://doi.org/10.1007/s10490-018-9590-z

The following articles are intended for inclusion in the Special Section on Familial Organizations and International Business: Individual, Organizational and Institutional Variety in and beyond Asia. These were however published in a separate issue, Volume 37 Issue 1.

Tsang, E.W.K. Family firms and internationalization: An organizational learning perspective. Asia Pac J Manag 37, 205-225 (2020). https://doi.org/10.1007/s10490-018-9590-Z

Xu, K., Hitt, M.A. The international expansion of family firms: The moderating role of internal financial slack and external capital availability. Asia Pac J Manag 37, 127-153 (2020). https://doi.org/10.1007/s10490-018-9593-9

The online version of the original article can be found at https://doi.org/10.1007/s10490-018-9590-z; https://doi.org/10.1007/s10490-018-9593-9

Kimberly A. Eddleston

k.eddleston@northeastern.edu

Peter Jaskiewicz

peter.jas@uottawa.ca

Mike Wright

mike.wright@imperial.ac.uk

1 D'Amore-McKim School of Business, Northeastern University, Boston, MA, USA

2 Telfer School of Management, University of Ottawa, Ottawa, Canada

3 The Centre for Management Buy-out Research, Imperial College, London, UK

4 ETH, Zurich, Switzerland 